\title{
Homo economicus in a Big Society: understanding middle-class activism and NIMBYism towards new housing developments
}

Problems of housing supply and affordability in England have long been recognised by policy-makers. A key barrier to supply is seen to be community activism by socalled NIMBYs (not-in-my-back-yard). The localism policy agenda, or devolving decision-making down to the local level, is central to how the UK Coalition government seek to overcome this opposition. This conceives NIMBYism as a demonstration of homo economicus - of the rationality of economic beings seeking to maximise their utility. In this view, residents would not accept large urban extensions in suburban areas because they took on localised costs with no obvious benefits, unless incentivised appropriately. In this paper we use analysis of British Social Attitudes Survey data as well as the results of the first review of middle-class activism in relation to public services to identify the likelihood of residents being incentivised by this version of localism to accept new housing. We conclude that the evidence on the individual and collective attitudes suggests that it is unlikely that localism will deliver new housing. Importantly, the political power of affluent and professional groups means they can ensure that their opposition is heard, particularly in the neighbourhood plans delivered through localism. The paper argues that planning for housing needs to understand communities as homo democraticus as actively engaged in negotiating between complex interests with respect to support for new housing.

Prof. Glen Bramley, Dr Peter Matthews, Heriot-Watt University; Prof. Annette Hastings, University of Glasgow

\section{Introduction}

The paper is concerned with the potential impact of the UK Coalition Government's 'localism' and 'Big Society' agendas on the system of planning for housing and providing land for new housing in England. Since the publication of the Conservative Party's pre-election "green paper" Open Source Planning (2009) and its implementation in the Localism Act 2010, a regime change in planning has begun (Allmendinger and Haughton, 2012). Previous policies with housing targets advised by the UK Government and delivered through regional planning, have been replaced by a policies favouring 'localism' and local 'empowerment'. Thus, under these reforms, decisions are to be devolved to the local level, ideally through new neighbourhood plans written by local communities, or through the Local Plan of a planning authority. The overall policy narrative is that planning has moved away from top-down, central targets, particularly for housing, and that local communities are empowered to decide what development they want and where (Communities and Local Government, 2010).

These reforms to the system of planning for new housing are thus one of the most dramatic and far-reaching ways that the intellectual project of the Big Society and its 
associated localism policies has had an impact on public policy (Allmendinger and Haughton, 2012, Baker and Wong, 2012). This is very much a reform driven by an imperative to remove central state involvement within a policy area and give power to local communities (Conservative Party, 2009). The national or regional scale is no longer seen as appropriate for making strategic decisions as to where housing will get built (Allmendinger and Haughton, 2012). However, it requires the "Big Society" on the ground to be delivered. Here we understand the "Big Society" as encapsulating a revival of civic society, communitarianism and paternalist self-help as a counter to "Big Government" (Blond, 2010; Macmillan, 2013; Sage, 2012). For neighbourhood planning to be successful communities need cohesive groups with enough capacity to consult widely and negotiate a highly technical system and produce an approved plan.

We are concerned here with whether these reforms in planning for housing will therefore enable affluent, well-educated and well-connected groups to oppose new housing development. With regard to the reforms of the planning system contained in the Localism Act (2010) and neighbourhood planning, this may be particularly the case in areas of high development pressure such as the South East of England and 'there is concern and criticism that these changes might result in a drastic reduction in new homes approved and built' (Buser, 2012: 12; Allmendinger and Haughton, 2012, Inch, 2012, Jacobs and Manzi, 2012, Lowndes and Pratchett, 2012, Sullivan, 2012).

To interrogate whether the Coalition's localist planning policies will empower middleclass community groups to oppose new housing developments, we first of all theorise opposition and analyse how it is understood in policy. We suggest that the localist policies view opponents as homo economicus - as individuals responding to costs and benefits. We contrast this view of opposition with a view which conceives of individuals within broader socio-political structures operating as homo democraticus. We then use a two-stage analysis to apply this to predict whether localism will lead to a reduction in new housing being built. The first stage is to analyse the British Social Attitudes Survey (BSAS) (Park et al., 2011) in order to understand the geographical extent of resistance to new development, its conditionality and its relationship with the political allegiances of people in these areas. The second is to explore the implications for this context of a theoretical model of middle-class community activism produced by the authors designed to understand the impact of self-interested affluent, or middle-class, residents on public service distribution. (anonymous and anonymous 2013). Together both stages of the analysis suggest that it is very unlikely that the UK Government reforms of planning for housing will produce an increase in housing delivery.

\section{Theorising and explaining planning for housing and local opposition in England}


Land use planning has been and remains one of the most powerful regulatory interventions in the UK. It is important to note that the planning system in the UK has been devolved to the four nations and regions which have developed their own reforms; in this paper we focus on the English system and particularly planning for housing (Cullingworth \& Nadin, 2006). The regulatory power of the planning system remains largely in place despite a prolonged period (since 1979) when governments of all main parties have embraced a market-led approach to economic policy, supporting market processes rather than regulating or challenge them, including to some extent within development planning (Allmendinger and Haughton, 2012). However, there has long been a recognition that the English planning system has failed to deliver new housing development due to the expression of collective opposition through the electoral process, and in processes of planning for new housing themselves (Hall, 1973, Sturzaker, 2010). The period around 2004 saw the 'sudden rediscovery' of housing supply as a major policy issue in England after thirty years' slumber (Bramley 2007), crystallized in the Barker Review (2004) and the then UK Government's quite strong policy response to this (Barker, 2006). This paralleled planning reforms in England with the introduction of Local Development Frameworks and Regional Spatial Strategies, meant to streamline the plan-making process and thus plan-led decisions (Baker and Wong, 2012). Housing demand was strong and house prices rose to unprecedented levels which, despite low interest rates, represented a real deterioration in affordability in this period. The analysis by Kate Barker concluded that

'At the centre of these recommendations is the principal objective that planning should take more account of, and use market information...Central to achieving change is the recommendation to allocate more land for development...A stronger role for regional planning bodies is recommended,...charged with setting out advice on market affordability targets, housing numbers, strategic growth areas, and co-ordinating links between the key players'.

(Barker, 2004, p.6)

In delivering the new plans, Regional Development Agencies and local planning authorities had to use long-term housing market analysis and provide sufficient land to maintain a housing supply that maintained affordability. Planning agreements became more important, including the delivery of significant shares of affordable housing (Crook et al 2010). All of this policy effort produced a relatively small result on the ground. Annual housing output in England in this period (2007-08) comprised 170,000 private and 27,000 social completions, making 198,000 in all; in the best year, 2007, the total was 225,000), against estimates of requirements in the range 240-300,000 (NHPAU 2008). The economic crash after 2007 led to a steep fall in output, dropping to nearer 100,000 in 2009.

It is frequently observed that the most prevalent attitude towards new development, particularly housing, in the UK is the one captured by the pejorative NIMBY label. 
Organisations that are strong voices within the planning system, such as the Campaign for the Protection of Rural England, have supported policies such as greenbelt around urban areas and opposition to rural development, increasingly using a discourse of sustainability, to actively resist any development in urban-rural fringe and rural areas (Sturzaker, 2010, Sturzaker and Shucksmith, 2012). For the UK Conservative party this has been a particular challenge as they need to balance their desire to allow the market to deliver new development where it is needed, while responding to an electorate that largely lives in suburban and semi-rural commuting villages and who are strongly opposed to new development. These are individuals who demonstrate NIMBY tendencies - as shown by a number of high-profile cases where Cabinet Ministers have opposed new housing development in their own constituency while at the same time advocating its necessity at a national level. There is a stereotypical view that this attitude to development is predominantly held by more affluent households, that we might term "middle-class" in the UK, and who are newer residents to suburban or semi-rural areas (Sturzaker, 2010). From this perspective, opposition is entirely selfish and self-serving, often the result of opponents wishing to maintain the value of their own property, or recreate an imagined rural idyll (Sturzaker, 2010; Sturzaker and Shucksmith, 2012).

During the period of expansionist planning policy, this manifested itself in strong opposition to "top-down" housing targets, particularly in the south-east of England and similar affluent, commuter-belt areas (Baker and Wong, 2012, Inch, 2012). This provided the Conservative party with an issue with strong political traction in key marginal constituencies. In Open Source Planning, published before the election, they described how they would abolish 'the entire bureaucratic and undemocratic tier of regional planning, including the Regional Spatial Strategies' and introduce a system where:

'local people in each neighbourhood - a term we use to include villages, towns, estates, wards or other relevant local areas - will be able to specify what kind of development and use of land they want to see in their area. This will lead to a fundamental and long overdue rebalancing of power, away from the centre and back into the hands of local people.'

(Conservative Party, 2009: 2)

That this could lead to a reduction in new development was implicitly incorporated into the argument of Open Source Planning - after all many Conservative MPs, including the Prime Minister and Chancellor of the Exchequer - had to contend with vocal opposition to new development in their constituencies. Under the Localism Act (2010) in England, communities were given the power to develop a neighbourhood plan, led by either the local Parish Council or a Neighbourhood Forum (Buser, 2012). If a simple majority of residents in a local referendum supported the plan, and it was aligned to broader local and national policy, then it would be adopted as the development plan for the area. Subsequently it was proposed that if communities 
accepted new housing then they would receive greater local investment through a reformed Community Infrastructure Levy and a New Homes Bonus where the increased tax base would be matched by an extra contribution from central government for five years (Conservative Party, 2009). Further, the Community Infrastructure Levy (CIL), proposed by the previous government, is being implemented to streamline the process of receiving planning gain from developers. Further reforms from April 2013 mean that up to a quarter of CIL can be given to Parish or Town Councils if they had a neighbourhood plan in place.

Unpacking this policy logic in the Conservative "green paper" Open Source Planning NIMBYs are conceived as homo economicus - they are individuals driven by a desire to maximise their own utility and who will respond to economic incentives. Thus a version of localismthat eventually devolves decisions down to individuals and their choices in a market makes narrative sense as a policy story (Conservative Party, 2009; Stone, 1989). Local communities gained no or little benefit themselves from new development; the largest impact was highly localised costs in terms of pressure on existing services, reductions in residential and environmental amenity and, ultimately, slower house price rises and it was this that drove NIMBY-type activism. Employing the market logic embodied by homo economicus, the Conservatives argued that if communities were financially incentivised to accept new development then 'Open Source planning will engage local communities and foster a spirit of innovation and entrepreneurship' in delivering new development (Conservative Party, 2009: 2).

However, we suggest that residents are better understood as homo democraticus individuals within wider socio-cultural structures. The literature which interrogates and criticises the NIMBY concept recognises that much of the opposition is valid and linked to broader societal concerns such as sustainability and social justice (see: Sturzaker, 2011 and Ellis, 2004 for overviews). This opposition to new housing can also be understood as a 'social gap' - many recognise the need for more new housing stock, particularly to increase affordability, while planning applications have relatively low success rates (Sturzaker, 2011: 558). Further, they bring their sense of elective or selective belonging to debates on place and place-making (Watt, 2009, Savage, 2010). These residents' sense of self, social position and belonging to a locality is based on their view of their neighbourhood, its history or rurality, for example. If this view is threatened by new development then they will oppose this forcefully (Watt, 2009). As such, opponents bring complex interests, including their economic self-interest, to debates around planning for housing. Further, our review of middle-class community activism (Anonymous and Anonymous, 2013) demonstrates how such groups can be particularly adept at making their interests heard in policy and development decision-making processes. In this way these people can be considered the embodiment of the Big Society as civic activism, not as atomistic individuals in the mould of homo economicus. Indeed, the danger recognised by many is that localism and the Big Society may empower communities 
and individuals who are already quite powerful (Anonymous and Anonymous, 2013 submitted).

\section{Predicting opposition to new housing}

The implementation of the planning proposals in the Localism Act has been understandably slow. Planning processes, by their nature, are often delayed and the recession has stalled much new development. Although there has been much enthusiasm for neighbourhood planning, cuts to planning authority budgets, and very little resourcing from the Department for Communities and Local Government (DCLG; the UK Government department that has national oversight of planning and housing policy) after the first 14 pilot areas, means progress on developing plans has been slow. A National Audit Office report into the New Homes Bonus identified major problems with the ability of government to measure its success (National Audit Office, 2013). It is difficult, if not impossible, to identify housing that has been delivered specifically because of the bonus, and indeed much of the housing is likely to have been planned before the bonus was introduced. Despite these identified difficulties in evaluating and analysing the localist reforms to the English planning system we can begin to predict what some of its outcomes will be, particularly its impact on the planning stance of local planning authorities. To do this we combine two analyses to answer two research questions:

1) How strong is opposition to new development and how does its spatial distribution coincide with development pressures in England?

2) Will the logic of Open Source Planning as implemented in the localism reforms of the planning system overcome opposition to new development from middle-class communities?

To answer the first question we have predominantly relied on analysis of the British Social Attitudes Survey presented below. These data collected in 2009-10 asked a representative sample of around 3,000 people in England, Wales and Scotland their attitude to new housing development in their neighbourhood. Further, respondents were asked what additional benefits from new development would be required for them to shift to support new housing development.

To answer the second research question, we use the outputs of a review of research on community activism by affluent or middle-class individuals and groups (Anonymous and Anonymous, 2013). This reviewed 69 studies across public services in the UK, USA and Scandinavian nations and used a realist synthesis methodology to develop middle-range theory that explains what works, in what contexts and how (for more detail on this methodology see: Pawson et al., 2005, Pawson, 2006). It uses a "context-mechanisms-outcomes" (CMO) framework to unpack the logic by which an intervention in society (usually a policy) might produce specific outcomes. In this case we sought to unpack how the mechanism of activism by more affluent groups and individuals might produce "the inverse care law" where 
service provision is in inverse proportion to need (Tudor Hart, 1971) or may create or exacerbate unequal service provision and outcomes in a range of different contexts $\left(C_{n}\right)$ (figure 1).

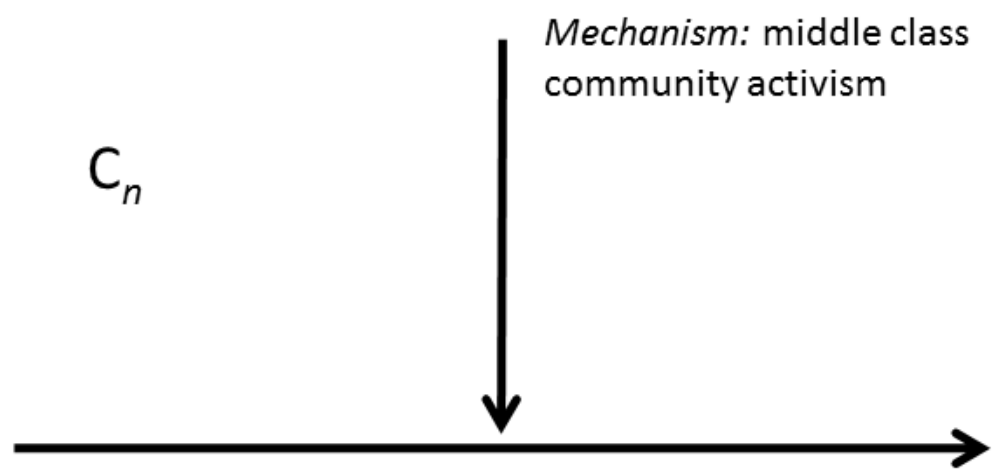

Outcome:

disproportionate benefit to middle classes

Figure 1 - CMO framework for middle-class community activism

The review synthesised the research evidence with a view to identifying a set of causal theories capturing mechanisms by which any outcomes may come about in specific contexts. The four 'causal theories' are presented in Table 1. These four causal theories can be used as rules of thumb, or heuristics, to examine what the outcomes in planning for housing may be of localism and associated policies. Thus they can be applied to the attitudinal data from BSAS to tease out what the likely outcome in policy processes for planning for housing might be.

Table 1 - Causal Theories of Middle-class Community Activism

\begin{tabular}{|c|l|}
\hline Causal theories & Description \\
\hline $\begin{array}{l}\text { 1. The middle-classes and } \\
\text { interest groups }\end{array}$ & $\begin{array}{l}\text { The middle-classes are more likely to join } \\
\text { groups, form groups, and these groups are } \\
\text { more important in policy-making (e.g. School } \\
\text { Governing Boards) }\end{array}$ \\
\hline $\begin{array}{l}\text { 2. The middle-classes as } \\
\text { individual } \\
\text { consumers/activists with } \\
\text { public services }\end{array}$ & $\begin{array}{l}\text { The middle-classes are more likely to } \\
\text { complain about public services. When they do } \\
\text { so they are more likely to get a positive } \\
\text { response and produce a virtuous circle. }\end{array}$ \\
\hline $\begin{array}{l}\text { 3. The alignment of cultural } \\
\text { capital between service } \\
\text { users and providers }\end{array}$ & $\begin{array}{l}\text { Middle-class services users are engaging with } \\
\text { middle-class service providers and this } \\
\text { alignment of cultural capital is likely to confer }\end{array}$ \\
\hline
\end{tabular}




\begin{tabular}{|l|l|}
\hline $\begin{array}{l}\text { 4. Public policies and services } \\
\text { generally favour the middle-- } \\
\text { classes }\end{array}$ & $\begin{array}{l}\text { Organisational processes and policies } \\
\text { normalise the needs and complaints of the } \\
\text { middle-classes }\end{array}$ \\
\hline
\end{tabular}

\section{The spatial distribution of NIMBY attitudes}

The general pattern of responses in the BSAS confirms widespread opposition to new housing development. Those opposed to local house-building outnumber those supportive of it by a ratio of $3: 2(45 \%$ vs $30 \%)$. While nationally those opposed to local building are not a majority of all respondents, they are clearly a majority of those who have a view, and more clearly still a majority of those who have a strong view $(15 \%$ vs $5 \%)$. If local political decisions are driven mainly by those who hold clear or stronger views and can get those views heard, then the prospects for increasing house-building would appear poor. Opposition to local house-building is stronger among homeowners, ( $51 \%$ vs $24 \%)$, with private renters more evenly split and social renters substantially in favour. This pattern is unsurprising and consistent with the homo economicus model of local residents (Dear, 1992). Home-owners are already housed and have an investment motive to protect existing amenity and value. Renters are less likely to be so well housed and do not have the investment motive, while social renters are generally less well-off and may new house-building as improving their chances of getting a better home.

The housing market in England is very uneven in terms of levels of affordability and relative shortage of housing with the greatest need generally acknowledged as being in the south and east of the country(Bramley \& Karley, 2005; NHPAU, 2009). With local decision-making the pattern of support or opposition across regions and types of areas is important. Table 2 shows that there is rather less support and stronger opposition in the south, compared with the north and midlands. London is more polarized, with positive support in inner London and quite strong opposition in suburban outer London. This matches existing, recognised patterns, with incomers to semi-rural areas in the south of England especially resisting development and is consistent with experience in the period 2004-2009 (Abram et al., 1996, Yarwood, 2002, Sturzaker, 2010, Inch, 2012). Research into housing numbers in the various draft stages of Regional Spatial Strategies demonstrated dramatic falls in projected housing numbers between draft plan and finalised plan stage in these areas, largely due to local opposition to new development (Sturzaker, 2010). 
Table 2: Support for or Opposition to More Homes being Built in Local Area by Broad Region

\begin{tabular}{lrrrrr}
$\begin{array}{l}\text { Support new homes built } \\
\text { in local area }\end{array}$ & $\begin{array}{l}\text { North \& } \\
\text { Midlands }\end{array}$ & \multicolumn{1}{c}{ South } & London & $\begin{array}{r}\text { Scotland } \\
\text { \& Wales }\end{array}$ & $\begin{array}{l}\text { Great } \\
\text { Britain }\end{array}$ \\
\hline Support strongly & $4.3 \%$ & $3.8 \%$ & $7.5 \%$ & $6.4 \%$ & $4.9 \%$ \\
Support & $24.6 \%$ & $22.7 \%$ & $26.7 \%$ & $32.4 \%$ & $24.8 \%$ \\
Neither support nor & & & & & \\
oppose & $24.9 \%$ & $21.4 \%$ & $17.6 \%$ & $21.1 \%$ & $22.5 \%$ \\
Oppose & $31.3 \%$ & $31.8 \%$ & $27.3 \%$ & $25.8 \%$ & $30.3 \%$ \\
Oppose strongly & $11.9 \%$ & $17.6 \%$ & $19.8 \%$ & $12.4 \%$ & $15.1 \%$ \\
It depends & $2.2 \%$ & $2.7 \%$ & $.9 \%$ & $1.5 \%$ & $2.0 \%$ \\
Don't know & $.9 \%$ & $0.0 \%$ & $.2 \%$ & $.4 \%$ & $.4 \%$ \\
\hline Total & $100.0 \%$ & $100.0 \%$ & $100.0 \%$ & $100.0 \%$ & $100.0 \%$ \\
Majority for Development & $-14.3 \%$ & $-22.8 \%$ & $-13.0 \%$ & $0.6 \%$ & $-15.6 \%$ \\
& & & & & \\
Sample number & 1432 & 1057 & 306 & 502 & 3297 \\
\hline
\end{tabular}

Source: British Social Attitudes Survey 2010: see Bramley 'Housing Attitudes and Changing Policies' in Park et al (2011)

Overlaying the regional patterns, there is a general tendency for support for new housing to be high in larger and more central city areas, where there is generally less spare land to build, and somewhat more support in both run-down industrial areas and remoter rural areas. From this analysis we can say that the stereotype of the middle-class NIMBY community activist in the south of England is broadly supported - the areas where opposition to development is strongest are suburban and small town areas in more accessible locations, particularly in the prosperous south of England.

\section{Understanding NIMBY attitudes in a localist planning system}

Turning to the causal theories derived from our earlier review and outlined in Table 1 , in light of data from BSASwe can begin to predict the likely outcomes of the spatial distribution of NIMBY attitudes. Indeed, much of the evidence for the first causal theory which suggested that affluent people and those in higher socio-economic groups are more likely to join influential groups, came from research into spatial planning processes in the UK (Anonymous and Anonymous, 2013). The possible inequities resulting from public engagement in the planning system has been a concern since the late 1960s and the publication of the Skeffington report (Damer and Hague, 1971). Importantly, under land-use planning legislation in the England the lowest level of local government - parish councils - are a statutory consultee that local planning authorities must engage with when drafting a development plan or deciding on a planning application. As Sturzaker (2010) and Yarwood (2002) suggest, parish councils, particularly in rural villages, are dominated by affluent or professional, older men, often with professional backgrounds.

Linking this to the second and third of the causal theories identified in Table 1, the highly technical land-use planning system also supports the accumulation and use of 
cultural capital, in this case conceived of as the knowledge, understanding and lingusitic resources appropriate to engagement with the system of planning for housing. To engage successfully with the planning system requires knowledge of technical planning language, complex technical terms - such as what constitutes a "material consideration" - and knowledge of the system itself and when it is most effective to engage. Studies of rural affordable housing provision demonstrate that middle-class parish council members are much more likely to have this knowledge and be able to apply it within the planning policy process (Yarwood, 2002, Sturzaker, 2010). The technical nature of planning processes enables the accumulation of this cultural capital as well. The study of the development planning process by Abram et al (1996) showed how affluent communities would fail to halt a development, but would then learn from this about how to influence the planning system more effectively and would succeed in relation to future developments. They can also call on their social capital, as social links to people of a similar social background, to increase their stock of cultural capital - for example through having a retired planner leading this role on a parish council or links to the legal profession to raise judicial objections to development proposals (Yarwood, 2002).

The framework of causal theories outlined in table 1 suggest that the planning reforms contained in the Localism Act could lead to a reduction in planned housing numbers as groups who are inclined to oppose development are empowered to do so. These opponents are homo democratus - they use social networks and influence to oppose new housing and produce their desired outcome. However, this does not tell us what it is that drives the opposition in the first place; is it merely economic selfinterest, albeit expressed through social networks rather than market decisions. The financial and local incentives implemented as part of the localism reforms of planning for housing (particularly the New Homes Bonus and other financial incentives) accept this view of homo economicus. The causal theory in this policy can be outlined as a CMO framework as in figure 2. This model includes no contextual variation - it is assumed in Open Source Planning and in the Localism Act that all communities are equally able to access and influence the planning system. The key to delivering new housing under this framework is to overcome the economic costs of new development for existing residents through local financial incentives. 


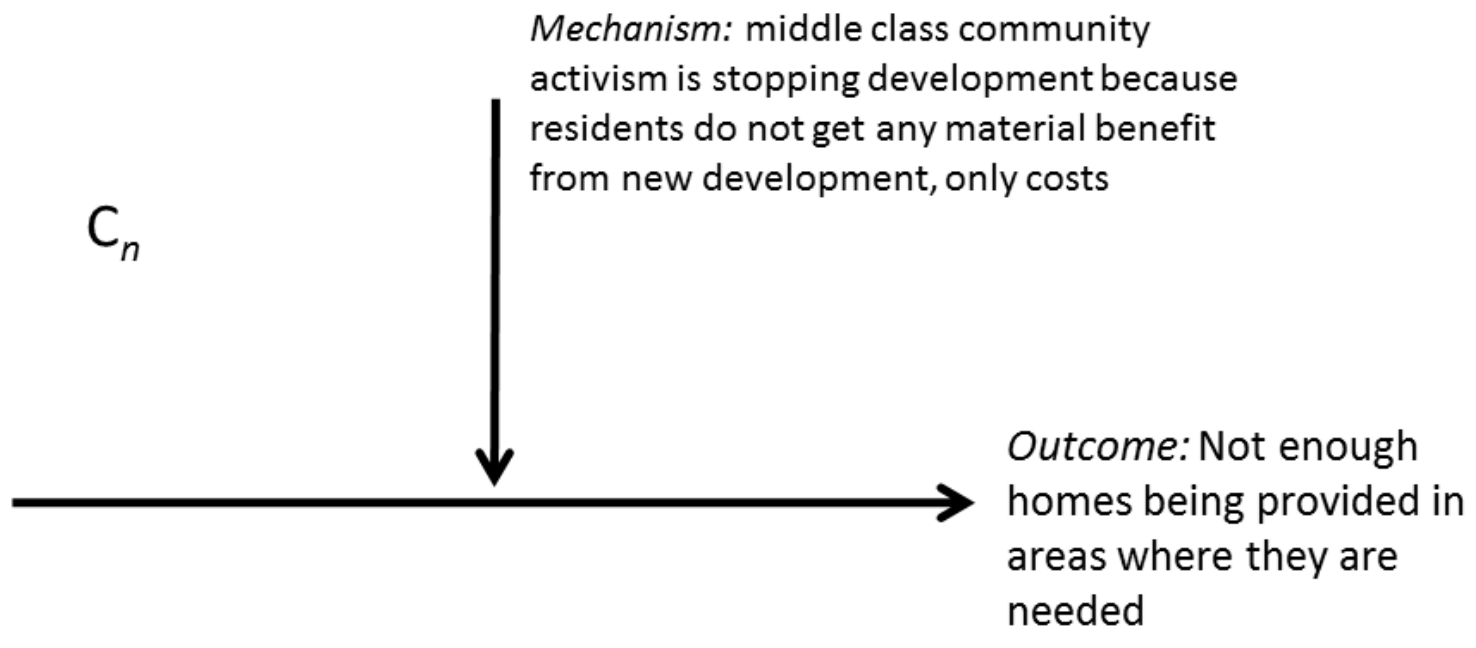

Figure 2 - CMO framework for homo economicus

Returning to the BSAS data we can understand and further model whether this is indeed the case. Table 3 below suggests that some additional benefits of planning gain could change some attitudes if they can be realistically promised and delivered. Two-thirds of those who opposed development less strongly and nearly four-fifths of those with no clear view could potentially be swayed to take a supportive position if local infrastructure was improved. Less than half of those strongly opposed to development could be swayed to a positive stance by any of these possible additional benefits. This does suggest that the model of the homo economicus NIMBY used in Open Source Planning is not an unrealistic portrayal of a selfinterested home-owner who would welcome new development if immediate local costs were mitigated.

Table 3: What advantages may persuade opponents to support new housing development

\begin{tabular}{lrrrr} 
& $\begin{array}{c}\text { Neither } \\
\text { support } \\
\text { nor }\end{array}$ & & & \\
oppose & Oppose & $\begin{array}{c}\text { Oppose } \\
\text { strongly }\end{array}$ & All \\
\hline More employment oppor's & 21 & 18 & 9 & 11 \\
More/improved green spaces/parks & 15 & 9 & 9 & 7 \\
Transport links improved & 11 & 12 & 7 & 7 \\
More/improved schools & 9 & 9 & 7 & 6 \\
More/improved leisure facilities & 7 & 7 & 5 & 4 \\
More/improved shops/supermarkets & 6 & 5 & 3 & 3 \\
More/improved medical facilities & 4 & 5 & 4 & 3 \\
Financial incentives to existing & 2 & 2 & 2 & 1 \\
residents & 2 & 1 & 0 & 1 \\
Other & 0 & 0 & 0 & 32 \\
Support+it depends & & & &
\end{tabular}




$\begin{array}{lrrrr}\text { New/improved library } & 0 & 1 & 0 & 0 \\ \text { None of these } & 22 & 31 & 54 & 23 \\ \text { It Depends/don't know } & 1 & 1 & 0 & 1 \\ \text { Total } & 100 & 100 & 100 & 100 \\ \text { Base } & & & & 3297\end{array}$

Source: British Social Attitudes Survey 2010: see Bramley 'Housing Attitudes and Changing Policies' in Park et al (2011)

However, different benefits have varying appeal, and it is clear that a package of several benefits would need to be credibly offered to change attitudes significantly. The most persuasive side benefit would be improved employment opportunities, as local communities tend to be concerned about economic wellbeing (Bramley \& Kirk 2005). Next most important is greenspace and parks: this is in fact relatively easy to provide as a by-product of housing so long as land is set aside for the purpose, although there may be issues about maintenance and quality and providing a more strategic supply of extensive, high-quality park land is more challenging. Improved transport links is unsurprisingly important. Much concern about new large housing development is the strain extra traffic would place on existing road infrastructure, particularly in suburban locations. Typical housing schemes generally entail road connections but securing adequate public transport can be more costly and difficult. Schools, leisure facilities and shops come next in the ranking, although these are commonly delivered through the planning system, such as the CIL and section 106 payments, or policies and conditions on mixed use developments.

We have to question how realistic it will be for the planning reforms to deliver these benefits and subsequently overcome opposition to new housing. It will be difficult to promise new employment as a by-product of a typical housing development, as this may require independent investment decisions by private businesses. Nevertheless in certain circumstances, including mixed use regeneration schemes and some rural situations, there may be a clear link with employment. Our review of middle-class activism found instances of local planning authorities and housing associations tactically using the provision of affordable housing for local people to overcome middle-class opposition by suggesting local rural economies would be supported (Yarwood, 2002). Further, while it has become increasingly common to receive contributions from developers for new green space, new schools, new transport infrastructure and affordable housing using a variety of mechanisms, in the immediate future with public capital programmes reduced severely, delivering these may become more difficult. Further, as mentioned above, initial implementation suggests that New Homes Bonus is supporting revenue spending in local authorities rather than capital investment in new infrastructure and facilities (National Audit Office, 2013).

\section{Predicting and explaining the impact of NIMBY attitudes to new housing in a localist planning system}


The BSAS data can provide a more generalised model of how attitudes towards local housing development line up, not just for different groups in the population but also for different geographical areas. We have therefore developed a two-step procedure to predict the local balance of opinion, conditional on various assumptions. The first step is to develop and test a multivariate logistic regression model to predict the odds of being a supporter or opponent of development. This can interrogate further the attitudinal evidence for the causal model outlined so far. Explanatory variables include a standard range of socio-demographic attributes of individuals and households, political affiliation and/or other general attitudinal/value proxies, and area type categories including some banded environmental characteristics of neighbourhoods or local authorities specially attached to the BSAS dataset for this purpose. Support for development may be unconditional or conditional, with four levels compared:

\section{Support development - no conditions}

2. Support development - assuming public open/greenspace and/or leisure facilities are provided/improved

3. Support development - assuming public open/greenspace and/or leisure facilities and/or education and/or healthcare and/or transport facilities are provided or improved

4. Support development - assuming public open/greenspace and/or leisure facilities and/or education and/or healthcare and/or transport facilities are provided or improved with opposition adjusted for those moderately opposed switching preference to supporting development.

Variables tested in these models include most of the socio-demographic attributes, political affiliation and area characteristics (for which local data sources like the Census, Index of Multiple Deprivation, voting figures and planning and land data could provide approximate equivalents). Variables which were not significant for either support or opposition at the different levels were discarded (although we retain all of the political variables). The resulting reduced models for support (1. above, unconditional) and opposition to development are shown in Table 5 below.

The model (tables 4 and 5 ) generally supports the contention that it is Conservative party-supporting, older people, people in social class three, and in rural areas who are most likely to be opposed to new housing development. Support for local housing development is greater, and opposition less, among families with children, private and social renters, flat dwellers and households on low incomes. In terms of political affiliation, Labour supporters are more likely to support development, and the same is true to a lesser extent for Liberal Democrats, whereas Green supporters are much less supportive of development.

Looking at types of geographical area, big city residents are more supportive whilst those in villages are less supportive of development. The key regional effect is that 
the South and Outer London are more negative about development. Those living in less deprived neighbourhoods (higher Council Tax banding value) are less supportive of development. Those living in areas which have been granting more planning permissions for housing and in areas with a lot of existing green space (undeveloped land) are more supportive of development, but those living in areas with a lot of designated statutory Green Belt are less supportive. These effects are mainly in line with expectations. However, it is not claimed that this is necessarily a causal model - we are simply trying to obtain a forecasting model to predict current levels of support and opposition.

\section{Table 4: Logistic Regression Models for Support and Oppose Development}

(British Social Attitudes Survey, 2010)

\begin{tabular}{|c|c|c|c|c|c|c|}
\hline Variable & $\begin{array}{l}\text { Support } \\
\text { Coeffic B }\end{array}$ & Signif & $\operatorname{Exp}(B)$ & $\begin{array}{l}\text { Oppose } \\
\text { Coeffic B }\end{array}$ & Signif & $\operatorname{Exp}(B)$ \\
\hline Retirement age & -0.212 & 0.063 & 0.870 & 0.189 & 0.057 & 1.208 \\
\hline Family with children & 0.337 & 0.001 & 1.430 & -0.137 & 0.137 & 0.872 \\
\hline Private renter & 0.291 & 0.030 & 1.238 & -0.506 & 0.000 & 0.603 \\
\hline Social renter & 0.653 & 0.000 & 1.563 & -0.494 & 0.000 & 0.610 \\
\hline Live in flat & 0.447 & 0.001 & 1.368 & -0.228 & 0.083 & 0.796 \\
\hline Social class 3 & -0.312 & 0.006 & 0.776 & 0.353 & 0.000 & 1.423 \\
\hline $\begin{array}{l}\text { Low income } \\
\text { Political affiliation }\end{array}$ & 0.212 & 0.052 & 1.206 & -0.042 & 0.679 & 0.959 \\
\hline Labour & 0.279 & 0.006 & 1.340 & -0.348 & 0.000 & 0.706 \\
\hline $\begin{array}{l}\text { Liberal Democrat } \\
\text { Other (BNP \& }\end{array}$ & 0.083 & 0.550 & 1.196 & -0.192 & 0.116 & 0.825 \\
\hline UKIP) & -0.201 & 0.504 & 1.036 & 0.278 & 0.274 & 1.321 \\
\hline $\begin{array}{l}\text { Green } \\
\text { Area attributes }\end{array}$ & -0.585 & 0.117 & 0.636 & 0.336 & 0.256 & 1.399 \\
\hline Big city & 0.069 & 0.700 & 1.224 & -0.295 & 0.089 & 0.745 \\
\hline Village & -0.234 & 0.111 & 0.676 & 0.404 & 0.002 & 1.498 \\
\hline $\begin{array}{l}\text { Low density } \\
\text { South/Outer }\end{array}$ & 0.064 & 0.668 & 1.001 & -0.232 & 0.081 & 0.793 \\
\hline London & -0.096 & 0.331 & 0.891 & 0.319 & 0.000 & 1.376 \\
\hline Very s & 0.407 & 0.000 & 1.290 & -0.329 & 0.000 & 0.720 \\
\hline $\begin{array}{l}\text { Very unsatisfied } \\
\text { area }\end{array}$ & 0.184 & 0.501 & 0.869 & 0.407 & 0.117 & 1.503 \\
\hline $\begin{array}{l}\text { Deprivation } \\
\text { banding } \\
\text { Planning Perm's }\end{array}$ & -0.177 & 0.000 & 0.878 & 0.123 & 0.002 & 1.130 \\
\hline ban & 0.016 & 0.039 & 1.016 & -0.007 & 0.296 & 0.993 \\
\hline Greenspace band & 0.078 & 0.006 & 1.057 & -0.110 & 0.000 & 0.896 \\
\hline Green Belt band & -0.062 & 0.003 & 0.965 & 0.077 & 0.000 & 1.080 \\
\hline Constant & -1.218 & 0.000 & 0.447 & 0.068 & 0.759 & 1.071 \\
\hline
\end{tabular}




\begin{tabular}{|c|c|c|c|c|c|}
\hline Overall model & 208.39 & 21 & 0.000 & 213.7 & 21 \\
\hline-2 Log Likelihood & 3051.7 & & & 3599.6 & \\
\hline Pseudo R Sq & $\begin{array}{r}\text { Cox\&Snell } \\
0.073\end{array}$ & $\begin{array}{c}\text { Nagelkerke } \\
0.105\end{array}$ & & $\begin{array}{r}\text { Cox\&Snell } \\
0.075\end{array}$ & $\begin{array}{c}\text { Nagelkerke } \\
0.100\end{array}$ \\
\hline $\begin{array}{l}\% \text { correct } \\
\text { predictions }\end{array}$ & 73.1 & & & 61.0 & \\
\hline
\end{tabular}

The second step in this exercise is to move to the local authority (district) level of analysis and to apply the coefficients from these models to an equivalent set of variables compiled at that area level. It is necessary to do this because the BSAS sample size is not sufficient to take values directly from the survey at the level of district council. Data on socio-demographics and land and planning factors are taken from a dataset developed to support the development of a sub-regional housing market model (Andrew et al 2010), derived from the 2001 Census and other sources and in some cases updated to 2007. The political affiliation variables are mapped across to voting in the 2010 General Election, reapportioned from constituencies to local authority districts. Satisfaction with areas scores are derived from pooled data from the Survey of English Housing 1997-2007.

The resulting predicted levels of support and opposition at different levels of conditionality are shown in Table 5, for regions and two area typologies. The overall levels of support (unconditional) and opposition shown in the first two columns are similar to those found within the BSAS as reported in Table 2, giving a majority against development of $-16.5 \%$ of all (including those without a view), or $-23 \%$ of those with a view. This is the figure across the whole of England. At regional level the majority against development ranges from $-7.5 \%$ in the North East to $-24.4 \%$ in the South East. However, the most rural areas show a small majority in favour of development $(2.0 \%)$, compared with $-18 \%$ in both urban and slightly rural areas. There is also a slight majority for development in Central London (2\%), with stronger opposition in London suburbs (-31.5\%) and Prospering areas (-20.6\%).

Table 5: Predicted Support, Opposition and Majorities for Development Under Different Conditional Assumptions by Region and Type of Locality

\begin{tabular}{|c|c|c|c|c|c|c|}
\hline Area Type & $\begin{array}{l}\text { Support } \\
1\end{array}$ & $\begin{array}{l}\text { Oppose } \\
1\end{array}$ & $\begin{array}{l}\text { Pro- } \\
\text { devel } \\
\text { Majority } \\
1\end{array}$ & $\begin{array}{l}\begin{array}{l}\text { Pro- } \\
\text { devel }\end{array} \\
\text { Major } 2\end{array}$ & $\begin{array}{l}\begin{array}{l}\text { Pro- } \\
\text { devel }\end{array} \\
\text { Major } 3\end{array}$ & $\begin{array}{l}\begin{array}{l}\text { Pro- } \\
\text { devel }\end{array} \\
\text { Major } 4\end{array}$ \\
\hline \multicolumn{7}{|l|}{ GO Region } \\
\hline NORTH & 0.311 & 0.386 & -0.075 & 0.030 & 0.045 & 0.350 \\
\hline YORKS \& HUMB & 0.283 & 0.407 & -0.124 & 0.002 & 0.003 & 0.345 \\
\hline NORTH WEST & 0.278 & 0.421 & -0.144 & -0.026 & -0.021 & 0.320 \\
\hline EAST MIDLANDS & 0.311 & 0.368 & -0.056 & 0.053 & 0.070 & 0.365 \\
\hline WEST MIDLANDS & 0.276 & 0.416 & -0.141 & -0.027 & -0.021 & 0.310 \\
\hline SOUTH WEST & 0.287 & 0.459 & -0.172 & -0.080 & -0.054 & 0.292 \\
\hline
\end{tabular}




\begin{tabular}{lllllll} 
EAST & 0.267 & 0.491 & -0.224 & -0.131 & -0.111 & 0.239 \\
SOUTH EAST & 0.257 & 0.501 & -0.244 & -0.151 & -0.132 & 0.235 \\
LONDON & 0.285 & 0.472 & -0.188 & -0.085 & -0.072 & 0.316 \\
Total & 0.280 & 0.445 & -0.165 & -0.060 & -0.046 & 0.301 \\
\hline Urban-Rural & & & & & & \\
Urban & 0.274 & 0.454 & -0.179 & -0.064 & -0.057 & 0.311 \\
Some Rural & 0.273 & 0.455 & -0.183 & -0.081 & -0.067 & 0.278 \\
Quite Rural & 0.305 & 0.409 & -0.104 & -0.021 & 0.008 & 0.303 \\
Most Rural & 0.350 & 0.330 & 0.020 & 0.095 & 0.131 & 0.380 \\
\hline LA Supergroup & & & & & & \\
Cities and Services & 0.285 & 0.401 & -0.117 & 0.021 & 0.022 & 0.381 \\
Coastal and & & & & & & \\
Country & 0.304 & 0.420 & -0.116 & -0.035 & -0.005 & 0.294 \\
London Centre & 0.357 & 0.338 & 0.019 & 0.136 & 0.145 & 0.487 \\
London Cosmop & 0.318 & 0.491 & -0.173 & -0.089 & -0.061 & 0.342 \\
London Suburbs & 0.241 & 0.556 & -0.315 & -0.222 & -0.207 & 0.204 \\
Mining and & & & & & & \\
Manufact & 0.285 & 0.426 & -0.141 & -0.034 & -0.024 & 0.302 \\
Prospering UK & 0.266 & 0.472 & -0.206 & -0.113 & -0.095 & 0.250 \\
Total & 0.280 & 0.445 & -0.165 & -0.060 & -0.046 & 0.301 \\
\hline
\end{tabular}

Note on levels of conditionality: 1 . no conditions; 2 support if open space \& leisure provision; 3. support if wider range of public facilities including transport, education \& health; 4 . as 3. but allowing previous moderate opponents to switch to support.

Assuming a moderate level of delivery of public green/open space and leisure facilities accompanying new housing, the figures move towards near neutrality or in some cases positive support for development (level 2, column 4). Regions with majority support, albeit small, would include North East, Yorkshire \& Humber, and East Midlands. Support would be more clear-cut (9.5\% majority) in the most rural areas. Support would be also gained in Cities and Services and Central London. Increasing the planning gain 'offer' to include education, health and transport would see only a modest further move towards majority support, so long as we assume no actual opponents of development switch sides (Level 3, column 5). The only other area type to switch to supporting development is 'quite rural'. However, if we assumed that this broad planning gain offer in terms of public facilities was generally deliverable and that previous moderate opponents of development might thereby switch their view, then the picture is transformed, and you would then have clear majorities for development in all cases, column 6.

In line with broader evidence on community activism in planning, these results do suggest that if direct benefits can be delivered through new development then it is more often supported (Sturzaker, 2011). However, the evidence shows this is more complex than the homo economicus concept as utilised in Open Source Planning and presented in figure 2. In fact, the extent of what is required to assuage opposition highlights the extent of the misunderstanding of opponents. Looking at table 2 , direct financial incentives to overcome costs to residents, originally part of 
the Open Source Planning, and implemented to an extent in the NHB and CIL, have little impact on whether people would support new development.

While the analysis of attitudinal data suggests that typical resident-voters may be willing to agree, in a marginal way, to packages of new homes with additional community benefits, this may not be sufficient to increase the supply of housing. These preferences, which may be evenly balanced, have to then be translated through local political process - it is democratic processes, not market processes, that will decide where new housing gets built. The evidence from our review of middle-class activism aligns with this attitudinal data to support the concept of homo democraticus to describe these groups in two distinct ways. Firstly, the evidence shows that these groups who are most opposed are more likely to have the social capital to actively oppose development. As stated, they are more likely to be members of Parish Councils, statutory consultees in the planning system, and more likely to have contacts to planners and lawyers who can assist them in making an appropriate opposition (Abram et al., 1996, Yarwood, 2002, Holman and Rydin, 2012). Thus, although in any area there may not be a majority opposed to development, it is likely that in an electoral process they will get their voices heard or have broader impact on deliberative process (Sturzaker, 2011). Further, evidence from similarly controversial proposals, such as school closures, demonstrates the ability of these groups to successful deploy their knowledge and cultural resources to develop stronger coalitions; effectively ensuring people become more strongly opposed to development (Bondi, 1988, Archer, 2010). In particular, it is causal mechanism three - the alignment of cultural capital between aggrieved residents and local elected members - that may have particular salience in these cases.

Secondly, we have to have a more complex understanding of the motives behind this opposition, particularly recognising belonging to neighbourhoods and communities. The widespread opposition to development in the south and east is concerning as this is generally where villages and towns affected by in-migration by commuters who electively belong to a "historic" rural idyll (Watt, 2009, Savage, 2010, Benson and Jackson, 2012). As the literature on elective and selective belonging shows, much of the economic capital invested in housing is converted into symbolic capital a statement of the self and one's socio-economic position. As Savage (2010: 132) discusses, the location of one's home, its design and décor, are closely related to how people see themselves in the world and 'the middle class culturally engaged are actually highly vested in their location...What matters more is the sense that they live somewhere appropriate for "someone like me".' To put it simply, new development is not seen as a threat to people's investment in their homes, but a threat to their social identity. The neighbourhood would stop being for people like them. The strength of this feeling is demonstrated in research such as Watt's in which there is an account of resident's employing a lawyer to resist a proposed development that would reduce environmental amenity in their neighbourhood (Watt, 2009). More starkly in Sturzaker's research, a middle-class parish councillor explained their tactical use of 
the planning system to prevent new development: 'In order to keep riff-raff from [nearby city] out of the community you need this s106 agreement' suggest a more base snobbery, closely linked to belonging (Sturzaker, 2010: 1014). Thus the "offer" from the planning system to overcome opposition needs to be sufficiently rich to support a sense of local and self-identity; financial compensation will always be insufficient.

\section{Conclusion}

The neighbourhood planning proposals in the Localism Act have empowered local groups to produce their own plan which will be accepted as the key planning document for a locality so long as it is in line with national planning guidance as well as the local development framework produced by the local planning authority, and it is agreed at a local referendum. Although the UK Government has attempted to incentivise new development, the evidence suggests that the neighbourhood planning proposals are a policy mechanism that is particularly susceptible to causal theories of middle-class activism. In particular, Neighbourhood Plans may act as a vehicle for legitimisation of activist, influential opposition, driven by socio-cultural identity, as a spoiling tactic in debates about how much housing gets built where.

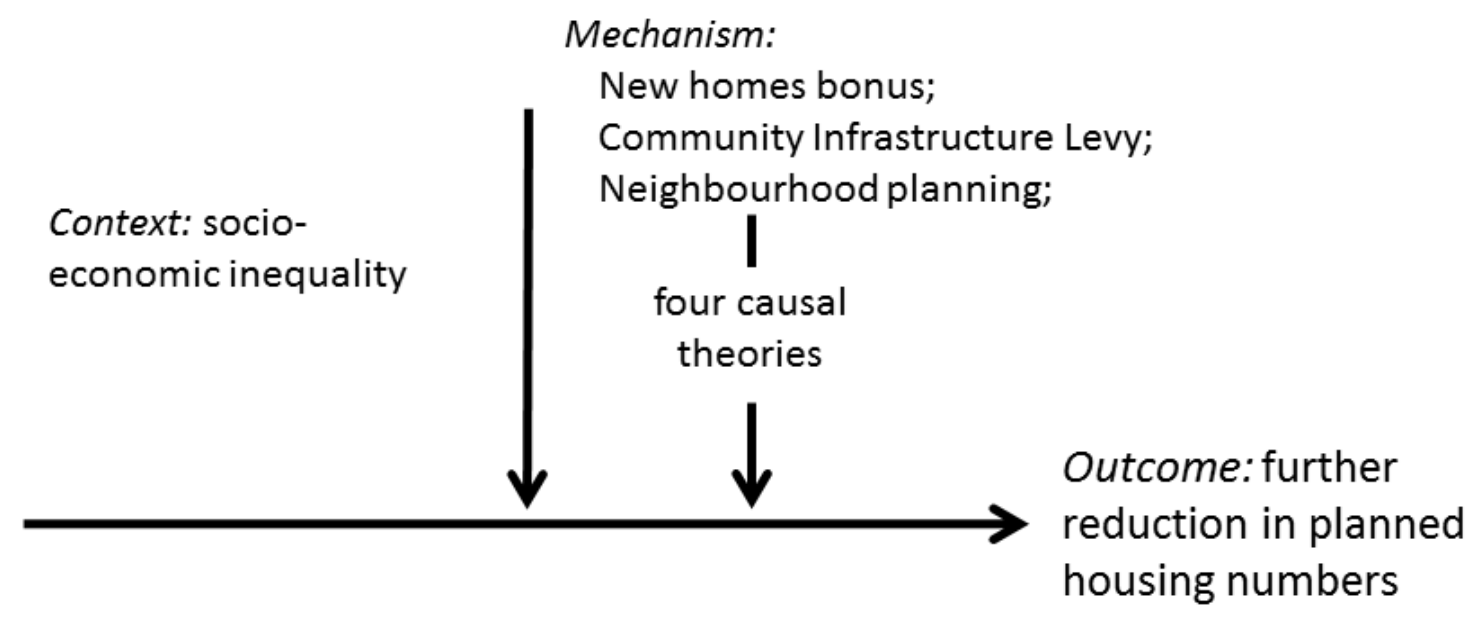

Figure 3 - CMO framework for housing delivery under Localism Act

The implementation of the reforms has actually produced mechanisms that are likely to support, rather than challenge, the existing bias towards affluent groups, heavily invested in their place, in the planning system (figure 3). For example, although any group can come forward to develop a neighbourhood plan, they need to secure a majority vote in a referendum. This has raised fears that less affluent would not have the resources, either in terms of time and money or cultural capital and knowledge of the planning system to come forward with their own proposals. The plans must also be in line with local, national and European policy and statute, for example requiring a strategic environmental assessment. Local authorities are meant to support local communities in developing the plans, however as they lose staff it is likely this 
support may not be forthcoming. The neighbourhood planning proposals therefore benefit those communities that can organise most successfully and those that can draw on their own expertise and cultural capital (Buser, 2012).

Further, the geography of opposition revealed through our analysis of BSAS data makes it doubly problematic. Opposition is greatest in places where new housing is most needed - the south and east - and it is in these types of areas we are most likely to see the elective and selective belonging of incoming commuter residents tied to self-identity and underpinned by emotional involvement, driving opposition. Returning to the concepts of localism and the Big Society, in promoting a conception of atomistic, individualised homo economicus who would respond to financial incentives in the localist planning for housing reforms, the government have inadvertently strengthened the broader, civic, Big Society. These opponents are the embodiment of the proposed transformation of English society - they are well connected with a strong sense of civic duty; volunteer for their parish council; and are highly invested in their community and neighbourhood. It is this that drives their successful opposition to new housing.

The key challenge that will therefore emerge for localist planning is whether the democratic fora developing neighbourhood plans - Parish Councils or neighbourhood forums - provide an adequate space for debate. The broad evidence on planning processes that are designed to empower communities demonstrates that a good, well mediated process can produce consensual planning outcomes among diverse stakeholders (Innes and Booher, 2010). The benefits required to overcome opposition to new development are such that it will be this level of collaborative working between communities, developers and local planning authorities that will be required to deliver new housing. Arguably, the 2003 Sustainable Communities plan from the former Office of the Deputy Prime Minister attempted this (ODPM, 2003) with proposals for higher quality housing development providing broad benefits to local communities. However, in practice such collaborative working takes time, investment and for participants to move beyond their individual interests and identify common interests. As noted by many commentaries on the Big Society and localism, while some of the policy intentions are worthy, without investment in community development they are unlikely to deliver empowerment (Bailey and Pill, 2011, Jacobs and Manzi, 2012, Sullivan, 2012). In a period of austerity, it is exactly these types of services, within planning departments and broader local government that are being cut (Hastings et.al. 2013).

\section{References}

Abram, S., et al. (1996). "The Social Construction of 'Middle England': The Politics of Participation in Forward Planning." Journal of Rural Studies 12(4): 353-364.

Allmendinger, P. and G. Haughton (2012). "The Evolution and Trajectories of English Spatial Governance: 'Neoliberal' Episodes in Planning." Planning Practice \&

Research 28(1): 6-26. 
Andrew, M., Bramley, G., Leishman, C., Watkins, D. \& White, M. (2010) NHPAU Sub-Regional Market Modelling Feasibility: Main Report on Model Testing and Feasibility. NHPAU/DCLG.

Archer, L. (2010). "'We raised it with the Head': the educational practices of minority ethnic, middle-class families." British Journal of Sociology of Education 31(4): 449469.

Bailey, N. and M. Pill (2011). "The continuing popularity of the neighbourhood and neighbourhood governance in the transition from the 'big state' to the 'big society' paradigm." Environment and Planning C: Government and Policy 29(5): 927-942.

Baker, M. and C. Wong (2012). "The Delusion of Strategic Spatial Planning: What's Left After the Labour Government's English Regional Experiment?" Planning Practice \& Research 28(1): 83-103.

Barker, K. (2004) Review of Housing Supply: Delivering Stability: Securing our Future Housing Needs. Final Report \& Recommendations. London: H M Treasury.

Barker, K. (2006). Barker Review of Land Use Planning: Final Report Recommendations. London, H M Treasury.

Benson, M. and E. Jackson (2012). "Place-making and Place Maintenance: Practices of Place and Belonging among the Middle Classes." Sociology.

Blond, P. (2010). Red Tory: How Left and Right have Broken Britain and How we can Fix It. London, Faber \& Faber.

Bondi, L. (1988). "Political participation and school closures: an investigation of bias in local authority decision making." Policy and Politics 16(Jan 88): 41-54.

Bramley, G. (2007) 'The sudden rediscovery of housing supply as a key policy issue' Housing Studies 22, 221-242.

Bramley, G., Bartlett, W., \& Lambert, C. (1995) Planning, The Market and Private Housebuilding. London: UCL Press.

Bramley, G. \& Karley, N.K. (2005) 'How much affordable housing is needed in England', Housing Studies.

Bramley, G. \& Kirk, K. (2005) 'Does planning make a difference to urban form? Recent evidence from central Scotland'. Environment \& Planning A. 37.

Buser, M. (2012). "Tracing the Democratic Narrative: Big Society, Localism and Civic Engagement." Local Government Studies 39(1): 3-21.

Conservative Party (2009). Open Source Planning: Green Paper. London, The Conservative Party.

Communities and Local Government (2010). Decentralisation and Localism Bill: An Essential Guide. London, HM Government.

Crook, A.D.H., Burgess, G., Dunning, R., Ferrari, E., Henneberry, J., Lyall Grant, F., Monk, S., Rowley, S., Watkins, C. and Whitehead, C. (2010) The incidence, value and delivery of planning obligations in England in 2007-08. London: Department of Communities and Local Government. 
Cullingworth, J. B. and V. Nadin (2006). Town and Country Planning in the UK. London, Routledge.

Damer, S. and C. Hague (1971). "Public participation in planning: a review." The Town Planning Review 42(3): 217-232.

Dear, M. (1992). "Understanding and Overcoming the NIMBY Syndrome." Journal of the American Planning Association 58(3): 288-300.

Ellis, G. (2004). "Discourses of objection: towards an understanding of third-party rights in planning." Environment and planning A 36(9): 1549-1570.

Hall, P. G. (1973). The Containment of Urban England: The planning system: objectives, operations, impacts, Allen and Unwin.

Hastings, A. and P. Matthews (2013, submitted). "Bourdieu and the Big Society: empowering the powerful in public service provision? ." Policy \& Politics.

Hastings, A., et al. (2013). Coping With the Cuts? Local Government and Poorer Communities. York, Joseph Rowntree Foundation.

Holman, N. and Y. Rydin (2012). "What Can Social Capital Tell Us About Planning Under Localism?" Local Government Studies 39(1): 71-88.

Inch, A. (2012). "Creating 'a generation of NIMBYs'? Interpreting the role of the state in managing the politics of urban development." Environment and Planning C: Government and Policy 30(3): 520-535.

Innes, J. E. and D. E. Booher (2010). Planning with Complexity: An Introduction to Collaborative Rationality for Public Policy. London, Routledge.

Jacobs, K. and T. Manzi (2012). "New Localism, Old Retrenchment: The "Big Society", Housing Policy and the Politics of Welfare Reform." Housing, Theory and Society: 1-17.

Lowndes, V. and L. Pratchett (2012). "Local Governance under the Coalition Government: Austerity, Localism and the "Big Society"." Local Government Studies 38(1): 21-40.

Macmillan, R. (2013). Working Paper 90: Making Sense of the Big Society: Perspectives from the third sector. Birmingham, Third Sector Research Centre.

Matthews, P. and A. Hastings (2013). "Middle-Class Political Activism and MiddleClass Advantage in Relation to Public Services: A Realist Synthesis of the Evidence Base." Social Policy \& Administration 47(1): 72-92.

National Audit Office (2013). The New Homes Bonus. London, The National Audit Office.

NHPAU (National Housing and Planning Advice Unit) (2008), Meeting the Housing Requirements of an Aspiring, Growing and Prosperous Nation: Advice to the Housing Minister about the Housing Supply Range to Be Tested by the Regional Planning Authorities, Titchfield, NHPAU.

NHPAU (2009) More Homes for More People: building the right homes in the right places. Titchfield: National Housing and Planning Advice Unit.

ODPM (2003). Sustainable Communities: Building for the Future. London, Office of the Dpeuty Prime Minister. 
Park, A., Curtice, J., Thomson, K., Phillips, M., Clery, E. and Butt, S. (2011) British Social Attitudes - the $26^{\text {th }}$ Report. London: National Centre for Social Research.

Pawson, R. (2006). Evidence-based Policy: A Realist Perspective. London, Sage.

Pawson, R., et al. (2005). "Realist review - a new method of systematic review designed for complex policy interventions." Journal of Health Services Research \& Policy 10(suppl 1): 21-34.

Sage, D. (2012). "A challenge to liberalism? The communitarianism of the Big Society and Blue Labour." Critical Social Policy 32(3): 365-382.

Savage, M. (2010). "Class and elective belonging." Housing, Theory and Society 27(2): 115-136.

Stone, D. A. (1989). "Causal stories and the formation of policy agendas." Political Science Quarterly 104(2): 281-299.

Sturzaker, J. (2010). "The exercise of power to limit the development of new housing in the English countryside." Environment and planning A 42(4): 1001-1016.

Sturzaker, J. (2011). "Can Community Empowerment Reduce Opposition to Housing? Evidence from Rural England." Planning Practice \& Research 26(5): 555570.

Sturzaker, J. and M. Shucksmith (2012). "Planning for housing in rural England: Discursive power and spatial exclusion." Town Planning Review 82(2): 169-194. Sullivan, H. (2012). "DEBATE: A Big Society needs an active state." Policy \& Politics 40(1): 141-144.

Tudor Hart, J. (1971). "The inverse care law." The Lancet 297(7696): 405-412.

Watt, P. (2009). "Living in an oasis: middle-class disaffiliation and selective belonging in an English suburb." Environment and planning A 41(12): 2874-2892.

Yarwood, R. (2002). "Parish Councils, Partnership and Governance: The Development of 'Exceptions' Housing in the Malvern Hills District, England." Journal of Rural Studies 18(3): 275-291. 